\title{
DETERMINAN PRODUKSI EKONOMI KREATIF SUBSEKTOR KULINER DI INDONESIA TAHUN 2011-2015
}

\author{
(Determinant OfCreative Economic Production Of Culinary Subsectors In Indonesia, 2011- \\ 2015)
}

\author{
Amalia Rizkiyani ${ }^{1}$, Atik Mar'atis Suhartini ${ }^{2}$ \\ Politeknik Statistika STIS ${ }^{1}$ Politeknik Statistika STIS² \\ Jalan Otto Iskandardinata Nomor 64C Jakarta, 13330 \\ E-mail: 15.8496@stis.ac.id
}

\begin{abstract}
ABSTRAK
Ekonomi Kreatif (Ekraf) merupakan salah satu sektor yang memiliki peranan penting dalam menunjang perekonomian Indonesia di era revolusi industri 4.0 saat ini. Meskipun dari waktu ke waktu Ekraf terus menunjukkan eksistensinya, namun hal tersebut belum mampu mendorong perekonomian Indonesia dimana pada tahun 2011-2015 justru menunjukkan perlambatan. Oleh sebab itu, pemerintah dan para pelaku Ekraf berusaha mencari berbagai cara untuk meningkatkan PDB Ekraf sebagai solusi untuk mendorong perekonomian Indonesia. Dari 16 subsektor yang ada, kuliner merupakan subsektor yang memiliki kontribusi tertinggi terhadap PDB Ekraf, sehingga peningkatan Ekraf subsektor Kuliner akan memberikan pengaruh yang besar terhadap keseluruhan PDB Ekraf. Akan tetapi pada tahun 2011-2015, pertumbuhan PDB Ekraf subsektor kuliner terus mengalami perlambatan yang menunjukkan adanya kendala yang dihadapi oleh para pelaku Ekraf subsektor kuliner dalam meningkatkan produksinya. Sehingga tujuan dalam penelitian ini yaitu: untuk menganalisis variabel-variabel yang mempengaruhi output produksi industri Ekraf subsektor kuliner, dan mengidentifikasi skala pengembalian pada industri Ekraf subsektor kuliner tahun 2011-2015. Metode analisis yang digunakan dalam penelitian ini adalah analisis regresi data panel dengan data Survei Perusahaan Industri Manufaktur dan Publikasi Statistik Industri Manufaktur Indonesia. Dengan model terpilih random effect model (REM), hasilnya menunjukkan bahwa variabel jumlah tenaga kerja dan bahan baku terbukti berpengaruh positif dan signifikan terhadap output produksi Ekraf subsektor kuliner. Sedangkan Ekraf sendiri dalam kondisi decreasing return to scale, artinya proporsi penambahan input lebih besar dari proporsi penambahan output yang dihasilkan.
\end{abstract}

Kata kunci: ekonomi kreatif, subsektor kuliner, regresi data panel

\section{ABSTRACT}

Creative Economy (Ekraf) is a sector that has important role in 4.0 industrial revolution era. Although Ekraf to show its existence but has not been able to boost the economy. The growth showed slowdown movements in 2011-2015. Therefore, the Ekraf actors are trying to increase Ekraf's GDP as one solution to improve the economy. Culinary as one of ekraf sub-sector have highest contribution to Ekraf's GDP, so increasing in culinary sub-sector income will influence on Ekraf's GDP. However, culinary sub-sector GDP decreasing slowly in 2011-2015. This paperaims to analyze variables that affectculinary subsector GDP and identifying it's returns to scale in 2011-2015 by panel data regression analysis. The results show that number of workers and raw materials have positive and significant impact on culinary sub-sector output. Cullinary sub-sector also got decreasing return to scale which mean increasing of input proportion is more than increasing in output proportion.

Keywords: creative economy, culinary sub-sector, panel data regression

\section{PENDAHULUAN}

Pada era industri keempat atau yang disebut juga revolusi industri 4.0 saat ini, Indonesia mulai memasuki sistem digitalisasi industri. Segala aktivitas baik fisik, mesin maupun data saling berkoneksi dalam menciptakan perekonomian yang lebih maju. Dalam perkembangannya, berbagai industri mulai mengembangkan diri dengan memanfaatkan berbagai teknologi dan data, salah satunya ialah industri yang bergerak dibidang ekonomi kreatif (Ekraf). Ekraf memanfaatkan 
kekayaan intelektual dan kreativitas manusia untuk menciptakan suatu produk yang memiliki nilai tambah lebih tinggi. Dengan kondisi bonus demografi di Indonesia yang diproyeksikan terjadi hingga tahun 2030, Indonesia memiliki peluang besar untuk mengembangkan Ekraf melalui banyaknya generasi muda yang produktif. Namun pada kenyataannya, hadirnya Ekraf belum mampu secara optimal mendorong perekonomian Indonesia. Pada tahun 2011-2015, laju pertumbuhan ekonomi Indonesia masih mengalami perlambatan. Di sisi lain, PDB Ekraf tahun 2011-2015 menunjukkan kenaikan setiap tahunnya. Pada tahun 2015, Ekraf mampu memberikan kontribusi sebesar 7,39 persen terhadap total perekonomian nasional. Hal ini tentu menjadi perhatian pemerintah dan para pelaku Ekraf untuk mencari berbagai cara guna mengoptimalkan potensi besar yang dimiliki Ekraf untuk mendorong perekonomian Nasional. Salah satunya dengan meningkatkan output produksi yang dihasilkan oleh sektor-sektor unggulan di dalam Ekraf.

Dari 16 subsektor yang ada di dalam Ekraf, terdapat 3 subsektor unggulan yang berkontribusi besar terhadap PDB Ekraf, salah satunya yaitu subsektor kuliner. Pada tahun 2015, subsektor kuliner mampu memberikan kontribusi sebesar 41,7 persen, artinya kuliner merupakan tulang punggung PDB Ekraf, sehingga peningkatan subsektor Kuliner akan memberikan pengaruh yang besar terhadap keseluruhan PDB Ekraf. Akan tetapi pada tahun 2011-2015, pertumbuhan PDB Ekraf subsektor kuliner terus mengalami perlambatan yang menunjukkan adanya kendala yang dihadapi oleh para pelaku Ekraf subsektor kuliner dalam meningkatkan produksinya. Oleh karena itu, berdasarkan identifikasi tersebut penelitian ini bertujuan untuk melihat variabel-variabel yang dapat mempengaruhi output produksi Kuliner Kreatif di Indonesia dan mengidentifikasi skala pengembalian pada industri Ekraf subsektor kuliner tahun 2011-2015. Dengan mengetahui faktor apa saja yang secara signifikan dapat mempengaruhi output produksi Kuliner Kreatif, diharapkan pemerintah dan para pelaku Ekraf dapat menyusun strategi yang tepat dalam menjalankan usaha Kuliner Kreatif. Dengan penyusunan strategi yang tepat, dan pemanfaatan faktor produksi yang efektif serta efisien, usaha Kuliner Kreatif akan dapat memberikan hasil produksi yang optimal.

Penelitian mengenai faktor-faktor yang mempengaruhi produksi pernah dilakukan oleh beberapa peneliti sebelumnya. Diana Ayu Ratnasari (2017) dalam penelitiannya yang berjudul "Determinan Produksi Ekonomi Kreatif Subsektor Kriya di Yogyakarta Tahun 2014" bertujuan untuk melihat apakah subsektor kriya, sebagai salah satu subsektor yang banyak menyerap tenaga kerja, masih mampu untuk menyerap tenaga kerja, dan bermanfaat bagi perusahaan untuk meningkatkan produksi. Data yang digunakan yaitu data Industri Besar dan Sedang (IBS) dari Survei Industri Manufaktur di Yogyakarta. Metode analisis yang digunakan yaitu metode estimasi FGLS dan heteroscedasticity-robust standard error. Hasil penelitian tersebut menyatakan bahwa tenaga kerja, dan bahan baku signifikan memengaruhi produksi kriya, sementara modal fisik tidak berpengaruh signifikan.

Fitriana Nur Rachmah (2017) dalam penelitiannya yang berjudul "Potensi Ekonomi Kreatif di Indonesia: Analisis Input-Output dan Ekonometrika" bertujuan untuk mencari leading sector ekonomi kreatif, kemudian dianalisis lebih lanjut faktor-faktor yang mempengaruhi outputnya. Data yang digunakan berupa Tabel I-O Indonesia dan data IBS dari Survei Industri Manufaktur Indonesia. Metode analisis yang digunakan pada penelitian tersebut ialah analisis Input-Output dan juga analisis regresi data panel. Hasil penelitian tersebut menunjukkan bahwa subsektor kriya merupakan leading sector dalam ekonomi kreatif di tahun 2014. Kemudian, variabel penanaman modal, tenaga kerja, listrik, serta bahan baku impor terbukti signifikan mempengaruhi output subsektor kriya. Sementara itu, variabel upah tiap tenaga kerja dan PMTB belum terbukti dapat mempengaruhi output subsektor kriya pada tahun penelitian.

Dari sisi produksi IBS, Navis Nagari (2015) dalam penelitiannya yang berjudul "Estimasi Fungsi Produksi Industri Besar Sedang di Indonesia tahun 2010-2013" memiliki tujuan untuk mengestimasi fungsi produksi IBS serta mengetahui pengaruh tenaga kerja dan modal terhadap output IBS. Data yang digunakan yaitu data IBS dari Survei Industri Manufaktur Indonesia. Metode yang digunakan pada penelitian tersebut adalah analisis data panel. Hasil penelitian menunjukkan bahwa variabel yang memengaruhi output industri besar sedang adalah jumlah tenaga kerja. 
Selanjutnya dari sisi kuliner, penelitian oleh Nofia Nur Rahmawati (2016) dengan judul "Analisis Faktor-faktor yang Mempengaruhi Produksi Roti", bertujuan untuk mengetahui adanya pengaruh tenaga kerja, modal, bahan baku dan lama usaha terhadap produksi roti. Metode yang digunakan dalam penelitian tersebut ialah analisis regresi berganda dengan menggunakan dataprimer. Hasil penelitian ini menunjukan secara parsial tenaga kerja dan modal memengaruhi produksi secara signifikan. Sedangkan bahan baku dan lama usaha tidak berpengaruh secara signifikan terhadap produksi. Penelitian lain oleh Zelly Tri Komala dkk (2017) yang berjudul "Analisis Faktor-faktor yang Mempengaruhi Produksi Industri Kecil Menengah Makanan Olahan Rendang Telur di Kota Payakumbuh Sumatera Barat (Studi Kasus: IKM Rendang di Kampung Rendang)", bertujuan untuk menganalisis pengaruh modal, tenaga kerja, dan bahan baku terhadap jumlah produksi perusahaan industri rendang telur di desa rendang di kota Payakumbuh, Sumatera Barat. Metode analisis yang digunakan pada penelitian tersebut ialah analisis regresi linier berganda dengan menggunakan data primer. Hasil menunjukkan bahwa secara parsial, modal dan bahan baku berpengaruh signifikan positif, namun tenaga kerja tidak signifikan berpengaruh positif terhadap jumlah produksi.

Berdasarkan identifikasi dan penelitian terkait yang telah dipaparkan, ada beberapa variabel yang dapat mempengaruhi output produksi Kuliner Kreatif, yaitu jumlah tenaga kerja, modal yang digambarkan oleh PMTB, bahan baku, serta bahan bakar \& listrik. Dengan didapatkannya variabel yang signifikan mempengaruhi output subsektor kuliner, diharapkan dapat menjadi bahan evaluasi dalam mengembangkan produksi di industri kuliner, sehingga subsektor ini dapat memberikan output yang mampu mendorong perekonomian Indonesia.

\section{METODE}

\section{Landasan Teori}

Produksi merupakan sebuah proses pengolahan sumber daya untuk menghasilkan suatu output baru yang memiliki nilai tambah berupa barang atau jasa, sehingga dapat bermanfaat dalam memenuhi kebutuhan hidup sehari-hari. Sumber daya yang digunakan sebagai input dalam proses produksi disebut faktor produksi. Pyndick dan Rubinfeld (2013) mengatakan faktor produksi dapat berupa tenaga kerja, modal, bahan baku, dan teknologi.

Mankiw (2009) mengatakan bahwa output barang dan jasa di dalam perekonomian bergantung pada dua hal. Pertama, banyaknya input yang berupa faktor-faktor produksi. Kedua, yaitu kemampuan untuk mengubah input tersebut menjadi output, yang direpresentasikan dengan menggunakan fungsi produksi. Dengan demikian, fungsi produksi merupakan dasar yang mampu menunjukkan bagaimana tingkat output produksi dan hubungannya dengan faktor-faktor produksi yang digunakan dalam sebuah proses produksi. Nicholson (2000) memaparkan hubungan antara input dan output dalam fungsi produksi sebagai berikut:

$$
Q=f(K, L, M, \ldots)
$$

dimana Q menggambarkan output perusahaan dari barang tertentu selama suatu periode, $\mathrm{K}$ menggambarkan mesin (modal) yang digunakan selama periode tersebut, L menggambarkan penggunaan input tenaga kerja, dan $\mathrm{M}$ mewakili bahan baku yang digunakan.

Fungsi produksi yang paling sering digunakan di dalam dunia ekonomi ialah fungsi produksi Cobb Douglas. Menurut Soekartawi (1990) hal ini karena penggunaannya yang sederhana. Fungsi produksi Cobb-Douglas dapat dirumuskan sebagai berikut:

$$
F(K, L)=A K^{\alpha} L^{\beta}
$$

dimana A merupakan parameter yang bernilai lebih dari 0 yang mengukur produktivitas teknologi. Sedangkan $\alpha$ merupakan elastisitas input modal dan $\beta$ merupakan elastisitas input tenaga kerja. 


\section{Sumber Data}

Data yang digunakan dalam penelitian ini merupakan data sekunder yang bersumber dari Badan Pusat Statistik dalam Survei Tahunan Perusahaan Industri Manufaktur (Survei IBS) dan publikasi Statistik Industri Manufaktur Indonesia dengan tahun yang digunakan yaitu tahun 2011 sampai dengan 2015. Individu dalam penelitian ini yaitu 7 industri berdasarkan kode KBLI 5 digit yang termasuk dalam Ekraf subsektor Kuliner berdasarkan konsep Bekraf. Industri tersebut yaitu industri produk roti dan kue, industri makanan dari cokelat \& kembang gula, industri kembang gula lainnya, industri makanan \& masakan olahan, industri kue basah, industri makanan dari kedele dan kacangkacangan lainnya bukan tahu tempe \& kecap, dan industri produk makanan lainnya.

\section{Metode Analisis}

Dalam penelitian ini digunakan metode analisis inferensia menggunakan analisis regresi data panel pada industri besar sedang berdasarkan kode KBLI 5 digit sebagai individu dalam periode 2011-2015. Penentuan variabel yang digunakan didasarkan pada fungsi produksi Cobb-Douglas dan penelitian terkait, yaitu output produksi sebagai variabel dependen dan jumlah tenaga kerja (jiwa), PMTB (rupiah), bahan baku (rupiah), dan bahan bakar \& listrik (rupiah) sebagai variabel independen. Sehingga model dapat dituliskan sebagai berikut:

lnOutput $_{i t}=\alpha+\beta_{1} \operatorname{lnTK_{it}}+\beta_{2} \ln P M T B_{i t}+\beta_{3} \ln B a h a n_{-}$baku $u_{i t}+\beta_{4} \ln B B L_{i t}+u_{i t} \ldots \ldots \ldots \ldots \ldots . . . . .$.

(3)

Keterangan:

Outputit

TKit

PMTBit

Bahan_bakuit

BBLit

: nilai output dari industri ke-i tahun ke-t

: jumlah tenaga kerja yang dibayar pada industri ke-i tahun ke-t

: nilai barang modal tetap dari industri ke-i tahun ke-t

: nilai bahan baku yang digunakan oleh industri ke-i tahun ke-t

: nilai bahan bakar \& listrik yang digunakan oleh industri ke-i tahun ke-t

\section{Langkah-langkah Analisis Data}

Berikut langkah-langkah dalam melakukan analisis regresi data panel:

1. Untuk mendapatkan model terbaik, langkah pertama yaitu melakukan Uji Chow untuk memilih antara CEM atau FEM. Jika keputusannya gagal tolak H0, maka pemilihan model dilanjutkan dengan Uji BP-LM untuk memilih antara CEM dengan REM. Namun jika keputusannya adalah tolak Ho, maka pemilihan model dilanjutkan dengan Uji Hausman untuk memilih antara FEM dengan REM.

2. Saat model terbaik yang terpilih adalah FEM, maka dilanjutkan dengan pengujian struktur varians-kovarians residualnya dengan Uji LM, apakah memiliki sifat homoskedastis atau heteroskedastis. Jika bersifat homoskedastis, maka estimasi dapat dilakukan dengan OLS. Namun jika sifatnya adalah heteoskedastis, dilanjutkan dengan menguji ada tidaknya crosssection correlation untuk melihat ada tidaknya autokorelasi. Jika sifatnya heteroskedastis dan tidak terjadi cross-section correlation, maka estimasinya menggunakan metode WLS. Namun jika sifatnya heteroskedastis dan terjadi cross-section correlation, maka estimasinya menggunakan metode SUR.

3. Setelah pemilihan model terbaik, dilakukan pengujian asumsi klasik untuk menguji apakah model sudah memenuhi asumsi. Asumsi klasik yang harus dipenuhi pada estimasi OLS adalah normalitas, homoskedastisitas, non multikolinieritas, dan non autokorelasi. Sedangkan apabila metode estimasinya GLS/FGLS, WLS, atau SUR, asumsi yang diperlukan hanya normalitas dan nonmultikolinieritas.

4. Jika semua asumsi sudah terpenuhi, selanjutnya melihat keberartian model melalui uji parsial dan simultan serta koefisien determinasinya. 
Tahapan-tahapan dalam analisis regresi data panel tersebut dapat dilihat lebih jelas melalui diagram alir analisis regresi data panel pada Gambar $\mathbf{1}$ berikut ini:

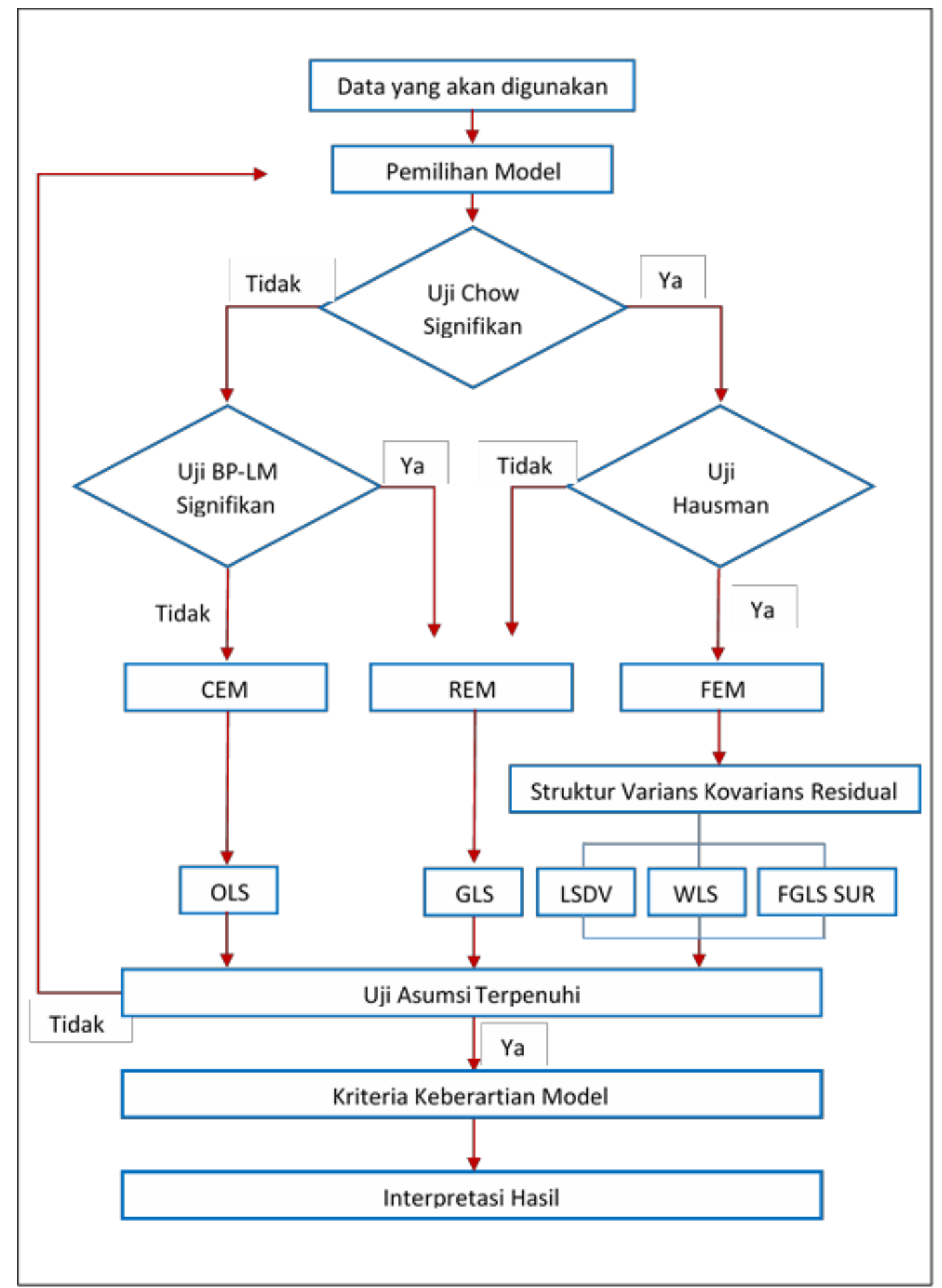

Gambar 1. Diagram alir analisis regresi data panel

\section{HASIL DAN PEMBAHASAN}

\section{Pemilihan Model Terbaik (Analisis Regresi Data Panel)}

Dalam melakukan analisis regresi data panel, terlebih dahulu dilakukan pengujian untuk menentukan model estimasi terbaik yang akan digunakan di dalam penelitian. Hal ini perlu dilakukan agar hasil estimasi dapat mendekati keadaan sebenarnya dan memenuhi kaidah statistik yang ada. 
Dalam data panel, terdapat 3 jenis model yaitu Common Effect Model (CEM), Fixed Effect Model (FEM), dan Random Effect Model (REM). Dari ketiga model tersebut dapat dijelaskan pengaruh setiap variabel bebas terhadap produksi industri kreatif subektor Kuliner.

Untuk menguji model manakah yang akan terpilih sebagai model terbaik, digunakan uji Chow, uji Hausman, dan uji BP-LM. Berdasarkan hasil uji Chow pada lampiran 1, pvalue bernilai 0,0008 dimana lebih kecil dari nilai taraf uji $(\alpha)$ sebesar 0,05 , yang artinya hipotesis nol ditolak. Dengan demikian, terbukti bahwa terdapat efek individu di dalam data sehingga FEM lebih cocok digunakan dalam menjelaskan pengaruh keempat variabel terhadap output produksi tiap industri dibandingkan CEM pada tingkat kepercayaan 95 persen.

Selanjutnya dilakukan uji Hausman untuk menguji model terbaik antara FEM dengan REM. Berdasarkan hasil uji Hausman pada lampiran 2, pvalue bernilai 0,2558 dimana nilai tersebut lebih besar dari nilai taraf uji $(\alpha)$ sebesar 0,05, yang artinya hipotesis nol tidak ditolak. Dengandemikian pada tingkat signifikansi 5 persen, REM merupakan model terbaik dalam menjelaskan pengaruh keempat variabel terhadap output produksi industri Kuliner.

\section{Pengujian Asumsi Klasik}

Selanjutnya setelah mendapatkan model terbaik, perlu diuji apakah model sudah memenuhi asumsi klasik regresi. Berdasarkan metode estimasi yang digunakan pada REM yaitu generelized least square (GLS), asumsi yang diperlukan pada model ini hanya dua uji yaitu uji normalitas dan nonmultikolinieritas. Hal ini dikarenakan metode GLS sudah mengatasi masalah heteroskedastisitas dan autokorelasi (Baltagi, 2008).

Berdasarkan hasil uji normalitas pada lampiran 3, nilai probabilitas pada uji Jarque-Bera adalah sebesar 0,5503 dimana nilai ini lebih besar dari nilai taraf uji $(\alpha)$ sebesar 0,05 , yang artinya hipotesis nol tidak ditolak. Dengan demikian residual dari model yang terbentuk berdistribusi normal, sehingga asumsi normalitas terpenuhi.

Selanjutnya, menurut Gujarati (2008) multikolinieritas terjadi jika VIF masing-masing variabel bebas bernilai lebih dari 10. Berdasarkan hasil uji multikolinieritas pada lampiran 4, tidak terdapat variabel yang memiliki nilai VIF di atas 10 . Artinya tidak terjadi multikolinieritas antar variabel bebasnya, sehingga asumsi nonmultikolinieritas terpenuhi.

Tabel 1. Output estimasi parameter persamaan regresi data panel fungi produksi Ekraf subsektor Kuliner

\begin{tabular}{|c|c|c|c|c|}
\hline Variabel & Koef & Std. Error & t-stat & Pvalue \\
\hline C & 5,27291 & 1,097926 & 4,802611 & 0,0000 \\
\hline LN JUMLAH TK & 0,19069* & 0,088892 & 2,145198 & 0,0201 \\
\hline LN PMTB & 0,02536 & 0,019458 & 1,303122 & 0,1012 \\
\hline LN BAHAN BAKU & $0,66534^{*}$ & 0,091887 & 7,240802 & 0,0000 \\
\hline LN BB \& LISTRIK (BBL) & 0,09077 & 0,079313 & 1,144448 & 0,1307 \\
\hline \multicolumn{5}{|c|}{ Ringkasan Statistik } \\
\hline R-squared & & 0,946909 & F-stat & 133,7678 \\
\hline Adjusted R-squared & & 0,939831 & Prob(F-stat) & 0,0000 \\
\hline
\end{tabular}

*Signifikan pada alfa $5 \%$ berikut:

Berdasarkan Tabel 1, maka persamaan regresi data panel yang terbentuk adalah sebagai

$$
\begin{aligned}
& \operatorname{Ln}(\text { Output })_{i t}=5,2729+0,1907^{*} \operatorname{Ln}(\mathrm{Jml} T K)_{i t}+0,0254 \operatorname{Ln}(\text { PMTB })_{i t}+ \\
& 0,6653^{*} \operatorname{Ln}(\text { Bahan Baku })_{i t}+0,0908 \operatorname{Ln}(B B L)_{i t}
\end{aligned}
$$

Berdasarkan persamaan tersebut diperoleh nilai Adjusted $\mathrm{R}^{2}$ sebesar 0,9398 yang berarti bahwa keempat variabel bebas di dalam model tersebut yaitu jumlah tenaga kerja, PMTB, penggunaan bahan baku, serta penggunaan bahan bakar dan listrik mampu menjelaskan output 
produksi subsektor Kuliner sebesar 93,98 persen. Sedangkan 6,02 persen dijelaskan oleh variabel lain yang tidak diteliti.

Selanjutnya, pada uji F-statistic akan dilihat apakah keempat variabel independen secara bersama-sama memiliki pengaruh terhadap output produksi tiap industri. Dengan pvalue sebesar 0,0000 , nilai tersebut lebih kecil dari nilai taraf uji $(\alpha)$ sebesar 0,05 sehingga tolak hipotesis dan dapat disimpulkan bahwa keempat variabel bebas di dalam model secara bersama-sama memiliki pengaruh terhadap output produksi subsektor Kuliner.

Secara parsial, dari keempat variabel bebas yang digunakan di dalam model, dua di antaranya berpengaruh signifikan terhadap output produksi yaitu jumlah tenaga kerja dengan nilai $t$-statistic sebesar 2,1452, dan bahan baku dengan nilai $t$-statistic sebesar 7,2408. Sedangkan dua variabel lainnya tidak signifikan mempengaruhi output produksi, yaitu PMTB dengan nilai $t$-statistic sebesar1,3031 dan bahan bakar \& listrik dengan nilai $t$-statistic sebesar 1,1444 dimana kedua nilai tersebut lebih kecil dibandingkan $\mathrm{t}(0,05 ; 30)$ sebesar 2,04227 sehingga gagal menolak H0. Keempat variabel bebas tersebut memiliki nilai koefisien yang positif, sehingga dapat diartikan bahwa jumlah tenaga kerja, PMTB, bahan baku, serta bahan bakar dan listrik berpengaruh positif terhadap output produksi.

\section{Jumlah Tenaga Kerja dengan Output Produksi}

Berdasarkan persamaan 4, jumlah tenaga kerja memiliki pengaruh yang positif dan signifikan terhadap output produksi industri Kuliner Kreatif. Artinya semakin banyak tenaga kerja yang dipekerjakan di industri tersebut, akan meningkatkan output yang dihasilkan. Hal ini juga mengindikasikan bahwa industri yang tergolong ke dalam Ekraf subsektor Kuliner merupakan industri yang padat karya, sehingga membutuhkan modal manusia yang cukup besar untuk dapat meningkatkan produksinya. Koefisien pada variabel jumlah tenaga kerja sebesar 0,1907 memiliki arti bahwa peningkatan jumlah tenaga kerja sebesar 1 persen, akan meningkatkan output produksi tiap industri Kuliner Kreatif sebesar 0,1907 persen, dengan asumsi variabel lainnya konstan (ceteris paribus). Hal ini sesuai dengan teori Cobb-Douglas yang menyatakan bahwa output produksi dipengaruhi oleh tenaga kerja. Selain itu, penelitian oleh Navis Nagari (2016) juga menunjukkan bahwa variabel tenaga kerja secara positif dan signifikan mempengaruhi output produksi industri pengolahan skala besar dan sedang.

\section{Bahan Baku dengan Output Produksi}

Bahan baku merupakan input utama dalam proses produksi industri Kuliner. Sebagai industri yang termasuk ke dalam industri pengolahan, industri Kuliner mengubah bahan baku yang belum diolah menjadi barang jadi yang siap dikonsumsi. Oleh karena itu, bahan baku merupakan salah satu penunjang utama output produksi. Semakin banyak bahan baku yang digunakan, semakin besar pula output yang akan dihasilkan. Hal ini juga terlihat pada hasil regresi data panel yang menunjukkan bahwa variabel bahan baku memiliki pengaruh yang positif dan signifikan terhadap output produksi industri Kuliner Kreatif. Artinya, semakin meningkat bahan baku yang digunakan, akan meningkatkan output produksi industri Kuliner Kreatif.

Sebagaimana dijelaskan sebelumnya pada bagian PMTB bahwa capital terbagi menjadi fixed dan variable, dimana bahan baku merupakan salah satu variable capital yang akan selalu diperlukan dalam setiap proses produksi. Sehingga secara langsung bahan baku akan mempengaruhi output Kuliner Kreatif secara signifikan. Hal ini juga sejalan dengan penelitian yang dilakukan oleh Diana Ayu Ratnasari (2017) yang hasilnya menunjukkan bahwa bahan baku memiliki pengaruh yang positif dan signifikan terhadap output produksi industri Kuliner Kreatif. Koefisien pada variabel bahan baku sebesar 0,6653 memiliki arti bahwa setiap peningkatan bahan baku sebesar 1 persen akan meningkatkan output produksi sebesar 0,6653 persen, dengan asumsi variabel lainnya konstan (ceteris paribus). Variabel bahan baku ini merupakan variabel yang memiliki pengaruh tertinggi terhadap kenaikan output produksi dibandingkan 3 variabel lainnya.

Variabel PMTB dan BBL tidak signifikan secara statistik mempengaruhi output produksi Kuliner Kreatif. Meski demikian, bukan berarti bahwa kedua variabel tersebut tidak memiliki pengaruh terhadap output, akan tetapi berdasarkan data yang ada belum cukup kuat untuk membuktikan pengaruh tersebut. Secara statistik, variabel PMTB tidak memiliki pengaruh yang signifikan 
2014 terjadi kenaikan PMTB yang sangat tinggi akibat munculnya 30 unit usaha baru dengan alokasi tertinggi untuk tanah, bangunan, mesin dan peralatan. Hal inilah yang menyebabkan secara statistik variabel PMTB menjadi tidak signifikan. Selain itu, kondisi ini sesuai dengan asumsi bahwa industri yang termasuk ke dalam Ekraf subsektor Kuliner pada penelitian ini merupakan industri yang lebih padat karya, sehingga modal manusia memiliki pengaruh yang lebih besar terhadap produksi dibandingkan alat dan mesin. Hal ini juga sejalan dengan hasil penelitian yang dilakukan Fitriana (2017) yang menunjukkan bahwa pengaruh PMTB terhadap output produksi Ekraf subsektor Kriya tidak signifikan.

Selain itu variabel bahan bakar \& listrik (BBL) juga memiliki pengaruh yang tidak signifikan terhadap output produksi industri Kuliner Kreatif. Peningkatan bahan bakar \& listrik belum mampu meningkatkan output produksi secara signifikan. Jika dilihat trendnya dari tahun ke tahun, terdapat ketidaksesuaian arah antara BBL dengan output pada tahun 2014 dan 2015 dimana peningkatan penggunaan BBL tidak diikuti dengan output produksi yang menunjukkan penurunan. Dan bila dilihat dari proporsinya, secara rata-rata proporsi biaya yang digunakan untuk bahan bakar dan listrik cenderung jauh lebih kecil dibandingkan biaya untuk modal dan bahan baku. Sehingga kondisi tersebut menyebabkan secara statistik variabel BBL menjadi tidak signifikan.

\section{Skala Pengembalian (Return to Scale)}

Persamaan regresi data panel yang dihasilkan pada penelitian ini merupakan hasil dari penurunan fungsi Cobb Douglas. Nilai elastisitas yang didapatkan dari persamaan tersebut berupa koefisien $\beta$, yang dapat digunakan untuk menjelaskan skala pengembalian. Saat jumlah elastisitas seluruh variabel bebas bernilai kurang dari 1 , maka skala pengembalian menurun. Sebaliknya jika jumlahnya bernilai lebih dari 1 , maka skala pengembalian meningkat. Namun jika jumlahnya sama dengan 1, maka skala pengembaliannya konstan. Jika persamaan regresi dikembalikan ke bentuk fungsi Cobb Douglas, maka persamaannya akan menjadi sebagai berikut:

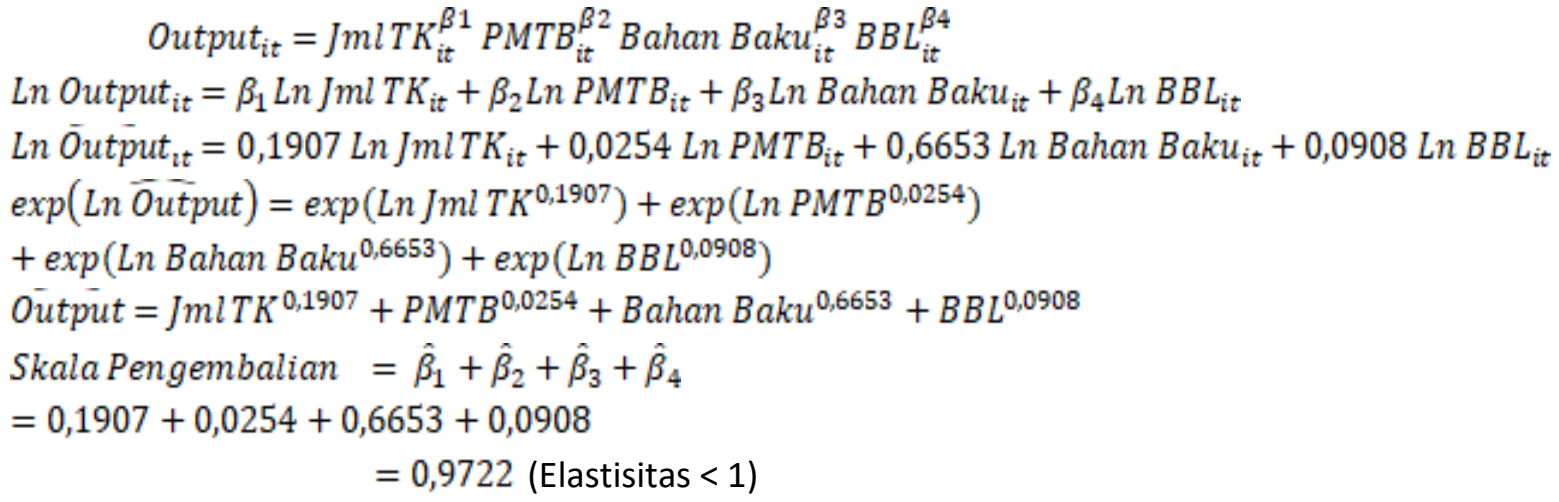

Hasil penghitungan elastisitas di atas menunjukkan bahwa terjadi decreasing return to scale (DRTS)atau skala pengembalian yang menurun. Artinya proporsi penambahan input jumlah tenaga kerja, PMTB, bahan baku, serta bahan bakar \& listrik lebih besar dari proporsi penambahan output produksi industri Kuliner Kreatif. Hal ini berarti setiap penambahan dari input di dalam penelitian hanya mampu meningkatkan output dengan jumlah yang lebih sedikit dibandingkan penambahan inputnya. Kondisi ini secara tidak langsung menggambarkan bahwa kurang efisiennya penggunaan input terhadap output produksi di industri Kuliner Kreatif. Hal ini diduga terjadi karena kondisi industri yang padat karya dengan tenaga kerja yang lebih didominasi oleh unskilled labor atau tenaga kerja yang tidak terampil. Sehingga produksi hanya dilakukan untuk memenuhi permintaan pasar tanpa memperhatikan produktivitasnya. 


\section{KESIMPULAN}

Berdasarkan hasil penelitian yang telah dijabarkan bahwa dari keempat variabel input, dua diantaranya berpengaruh positif dan signifikan terhadap variabel output produksi Kuliner Kreatif yaitu jumlah tenaga kerja dan bahan baku produksi. Sedangkan variabel PMTB dan bahan baku \& listrik (BBL) tidak signifikan mempengaruhi variabel output produksi Kuliner Kreatif. Skala pengembalian yang didapat menunjukkan terjadinya decreasing return to scale (DRTS) yang artinya proporsi penambahan input jumlah tenaga kerja, PMTB, bahan baku, serta bahan bakar \& listrik lebih besar dari proporsi penambahan output produksinya.

\section{DAFTAR PUSTAKA}

Badan Ekonomi Kreatif. (2016). Laporan Penyusunan PDB Ekonomi Kreatif Tahun 2010-2015. BEKRAF. Jakarta.

Badan Ekonomi Kreatif. (2017). Laporan PDB Ekonomi Kreatif Tahun 2014-2016. BEKRAF. Jakarta. Badan Ekonomi Kreatif. (2017). Rencana Pengembangan Kuliner Nasional 2015-2019. BEKRAF. Jakarta. Badan Ekonomi Kreatif. (2017). Rencana Strategis Badan Ekonomi Kreatif 2015-2019. BEKRAF. Jakarta. Badan Pusat Statistik. (2018). Dependency Ratio 2010-2035. BPS. Jakarta.

Badan Pusat Statistik. (2018). Statistik Industri Manufaktur Indonesia 2011-2015. BPS. Jakarta.

Badan Pusat Statistik. (2018). Survei Tahunan Perusahaan Industri Manufaktur 2011-2015. BPS. Jakarta. Baltagi, Badi H. (2005). Econometric Analysis Of Panel Data ( $3^{r d}$ ed). John Wiley \& Sons Ltd, England.

Gujarati, D.N dan D.C Porter. (2008). Basic Econometrics 5th Edition. McGraw-Hill, New York.

Ilhamuddin, M. (2016). Analisis Faktor yang Mempengaruhi Produksi Karet Alam dan Peranannya terhadap Perekonomian Indonesia Periode 2005-2013. Skripsi Sekolah Tinggi Ilmu Statistik. Jakarta.

Mankiw, N. Gregory. (2009). Macroeconomics (th ed). Worth Publishers, New York.

Nagari, Navis. (2016). Estimasi Fungsi Produksi Industri Besar Sedang di Indonesia Tahun 2010-2013.

Skripsi Sekolah Tinggi Ilmu Statistik. Jakarta.

Nicholson, W. (2000). Microeconomic Theory: Basic Principles and Extensions, ( $8^{\text {th }}$ ed). Thomson, South Western.

Rachmah, Fitriana N. (2017). Potensi Ekonomi Kreatif di Indonesia: Analisis Input-Output dan Ekonometrika.

Skripsi Sekolah Tinggi Ilmu Statistik. Jakarta.

Rahmawati, Nofia N. (2016). Analisis Faktor-faktor yang Mempengaruhi Produksi Roti. Skripsi Universitas Pasundan. Bandung.

Ratnasari, Diana A. (2017). Determinan Produksi Ekonomi Kreatif Subsektor Kriya di Yogyakarta Tahun 2014. Skripsi Sekolah Tinggi Ilmu Statistik. Jakarta.

Soekartawi. (1990). Teori Ekonomi Produksi: Analisis Cobb Douglas. Rajawali Press, Jakarta.

Trifosa, Grasela N. (2017). Faktor-faktor yang Memengaruhi Produksi Crude Palm Oil (CPO) di Kalimantan Tahun 2006-2014 (Penerapan Analisis Regresi Data Panel). Skripsi Sekolah Tinggi Ilmu Statistik. Jakarta.

Zelly, Tri Komala dkk. (2017). Analisis Faktor-faktor yang Mempengaruhi Produksi Industri Kecil Menengah Makanan Olahan Rendang Telur di Kota Payakumbuh Sumatera Barat (Studi Kasus: IKM Rendang di Kampung Rendang). Universitas Riau. Riau. 